\title{
Aristotelian Ethics and Luke 15.11-32 in Early Modern England
}

\begin{abstract}
The discourse surrounding Luke 15.11-32 — commonly titled 'the parable of the prodigal son' — in early modern England is a major site of convergence for Aristotelian and Christian ethics. During the sixteenth and seventeenth centuries, the perceived role of 'prodigality' (in the sense of excessive expenditure) in the parable of the prodigal son became deeply bound up with Aristotelian ethics; the parable's evolving title and its increasingly prominent role in casus summarii both contributed to and were affected by these changes. Despite the importance of both Aristotelian ethics and the parable of the prodigal son to early modern culture, scant research exists on the vital intersection between the two. By tracing the evolution of biblical paratexts, this article explicates how the parable gained its title. It then explores how the shared use of $\dot{\alpha} \sigma \omega \tau i \dot{\alpha}$ (prodigality) in Aristotle's Nicomachean Ethics and Luke 15.13 affected the interpretation of Luke 15.11-32 in early modern England, and the repercussions this had for early modern philosophy and theology. It concludes that Aristotelian ethics were hugely influential in both the early modern interpretation of Luke 15.11-32 and the concept of 'prodigality' that the parable was so often used to explore.
\end{abstract}

Keywords: prodigal, prodigality, Aristotle, Nicomachean, bible, parable, early modern, Luke, casus summarii. 


\title{
Aristotelian Ethics and Luke 15.11-32 in Early Modern England
}

'Prodigus, prodigall, wastefull, an outragious expender.'

\author{
Thomas Elyot, Bibliotheca Eliotae ${ }^{1}$
}

Lk 15.11-32, more commonly known as the parable of the prodigal son, is one of the most widely referenced and most frequently mis-quoted biblical episodes. In contemporary parlance, those described as prodigal sons rarely exhibit prodigal behaviour. The term predominantly functions as shorthand for Lk 15.11-32 rather than a literal descriptor. It is used to evoke the parable's pattern of loss and return, often with little applicability to the financial habits of the 'son' in question. The more nuanced meanings attached to prodigality have all but fallen by the wayside, not only in popular discourse but also among scholarship of periods - especially early modern England - in which such nuances are often vital to understanding a text. Almost no research exists on early modern financial prodigality, which creates serious blind spots in the study of Lk 15.11-32, economic philosophies, and Aristotelian ethics in early modern England. ${ }^{2}$

This article provides a preliminary bridge for this gap by explicating how Lk 15.11-32 came to be known as the parable of the prodigal son, what 'prodigal' had the potential to suggest at this time, and how these developments ultimately contributed to the decline of prodigality as a concept in popular knowledge. To do so, I demonstrate how early modern exegeses of the parable exhibit these issues in conjunction with the evolving landscape of biblical paratexts. My readings are especially concerned with John Donne's responses to the parable, which exhibit these themes with especial strength and detail. By comparing these paratexts and exegeses we are able to trace how the phrase 'prodigal son' shifted from merely a popular descriptor for Lk 15.11-32 to an official Anglican title.

The parable acquired this title gradually, shaped by evolving convention and popular authors, but its canonicity was cemented by its inclusion in the header to Lk 15 in the Geneva Bible. This occurrence is mainly attributable to the symbiotic ways by which translators and editors drew upon one another's work in conjunction with the etymological and philosophical influences acting upon biblical hermeneutics: specifically, the influence of Aristotelian ethics upon exegeses of Lk 15.11-32. I will explain the processes by which the parable acquired its title among English Christians, with reference to competing translations of the early Greek manuscripts in St. Jerome's Latin Vulgate and sixteenth century English translations,

\footnotetext{
${ }^{1}$ Thomas Elyot, Bibliotheca Eliotae (London, 1542), fol. D8v.

${ }^{2}$ For financial prodigality, see M. Prendergast, Renaissance Fantasies (London: Kent State University Press, 1999); J. Panek, "Community, Credit, and the Prodigal Husband on the Early Modern Stage," ELH 80.1 (2013): 61-92; A. Shepard, "Manhood, Credit and Patriarchy in Early Modern England c. 1580-1640," Past \& Present 167 (2000): 75106 and Meanings of Manhood in Early Modern England (Oxford: Oxford University Press, 2006); M. Dowd, The Dynamics of Inheritance of the Shakespearean Stage (Cambridge: Cambridge University Press, 2015), 117-162. For non-financial prodigality, see R. Helgerson, The Elizabethan Prodigals (Los Angeles: California University Press, 1976) and L. Hutson, The Usurer's Daughter (London: Routledge, 1994), 120-2.
} 
concentrating specifically on the intersection of Aristotelian ethics with Lk 15.11-32; in doing so I will address how one of Jesus' most famous parables became poised for some of the broadest and most varied interpretations among biblical hermeneutics.

This research was accomplished by examining and comparing several hundred texts, including codices, medieval to early modern Bibles, and a great many sermons, exegeses, and other religious writings. While it is possible some of the more obscure editions or oddities have been overlooked, I am confident that the substantial reading undertaken for this article is sufficient to draw the conclusions presented herein.

In order to discuss this title's genesis and history across English Bibles, I must first address its preceding translation from the Greek manuscripts into the Latin Vulgate. The germ of this title lies in the Greek text of what is now known as Lk 15.13, but which originally went undesignated. When compiling what would become the most influential translated Bible of the medieval era, Jerome translated the Greek $\zeta \tilde{\omega} v \dot{\alpha} \sigma \omega ́ \tau \omega \varsigma$ as vivendo luxuriose. This is not a perfect translation. $\dot{\alpha} \sigma \omega ́ \tau \omega \varsigma$ suggests wastefulness, riotousness, debauchery; as Clinton E. Arnold explains, 'The basic idea of the word is wastefulness and is often used in contexts of moral exhortation to describe a life that is devoid of virtue and representing a waste of time (contrasted to one who "redeems the time"). '3 Jerome's translation also shifts away from an adverbial construction in the Greek to an adjectival construction in the Latin, which is later maintained in the English translation, riotous living. Both $\zeta \tilde{\omega} v \dot{\alpha} \sigma \omega ́ \tau \omega \varsigma$ and vivendo luxuriose suggest wastefulness; however, $\dot{\alpha} \sigma \omega \epsilon \omega \varsigma$ can communicate a degree of financial specificity that vivendo luxuriose lacks. It may be telling that elsewhere Jerome refers to the parable as that of prodigus filius. ${ }^{4}$ The consequences of this are, perhaps surprisingly, quite dramatic.

We must turn to Aristotle's Nicomachean Ethics to comprehend the effects of this discrepancy. Aristotle provides the most comprehensive and influential explication of the concept of $\dot{\alpha} \sigma \omega \tau i \alpha$ in western philosophy. For Aristotle, each human quality exists as a mean virtue that can tend to the vices of excess or deficiency. Regarding financial behaviour, the mean is defined as $\dot{\varepsilon} \lambda \varepsilon v \theta \varepsilon \rho \imath \dot{\tau} \tau \eta \tau o \varsigma$ (liberality), the excess as $\dot{\alpha} \sigma \omega \tau i \dot{\alpha}$ (prodigality), and the deficiency as $\dot{\alpha} v \varepsilon \lambda \varepsilon v \theta \varepsilon \rho i ́ \alpha$ (meanness, also commonly denoted as covetousness or niggardliness). He defines prodigality and meanness thus (given the variety of early modern translations I quote from a twenty-first century edition): 'prodigality and meanness are excesses and defects with regard to wealth; and meanness we always impute to those who care more than they ought for wealth, but we sometimes apply the word 'prodigality' in a complex sense; for we call those men prodigals who are incontinent and spend money on self-indulgence.' He defines the liberal man as he who 'give[s] for the sake of the noble, and rightly; for he will give to the right people, the

\footnotetext{
${ }^{3}$ C. E. Arnold, Ephesians (Grand Rapids, Mich.: Zondervan, 2010), 349.

${ }^{4}$ Saint Jerome, Sancti Eusebii Hieronymi Epistulae, ed. Isidorus Hilberg ([Vienna and Leipzig]: F. Tempsky, G. Freytag, 1910-18), 1:11.
} 
right amounts, and at the right time, with all the other qualifications that accompany right giving. ${ }^{5}$ To be prodigal is to give (or spend) too much money, to be mean/niggardly is to give not enough, and to be liberal is to give moderately.

It has been argued that Luke was influenced by Aristotle, in which case Luke's use of $\zeta \tilde{\omega} v$ $\dot{\alpha} \sigma \omega ́ \tau \omega \varsigma$ may have evoked Aristotle's definition of prodigality. In recent years, numerous scholars have advocated the presence of Aristotelian influences in the New Testament discussions of economics and ethics, such as David Balch, Dieter Lührmann, Peter Balla, and David Holgate. ${ }^{6}$ Holgate concentrates specifically on the influence of Aristotle's discussions of vices and virtues on the New Testament moral codes. His focus is on Lk 15.11-32, wherein he identifies Aristotle as having especial influence on the Luke author's construction of the parable's moral structure. Holgate argues that Aristotle's Nicomachean Ethics offered a 'map' between prodigality, liberality, and meanness, and that 'his definition, illustration and evaluation of the key terms of $\dot{\alpha} \sigma \omega \tau i \dot{\alpha}, \dot{\alpha} v \varepsilon \lambda \varepsilon v \theta \varepsilon \rho i \alpha$ and $\dot{\varepsilon} \lambda \varepsilon v \theta \varepsilon \rho i o ́ \tau \eta \tau o \varsigma$ illuminate the basic moral configuration underlying the parable of the prodigal son. ${ }^{7}$ If Holgate's thesis is correct, then it is very possible that the $\zeta \tilde{\omega} v \dot{\alpha} \sigma \omega ́ \tau \omega \varsigma$ of Luke 15.13 was not only influenced by the Nicomachean Ethics but that these associations would be identifiable by Luke's contemporary readers. If so, the son's prodigality would have been understood in the terms of Aristotle's ethical qualities as a vice that has exceeded the bounds of virtuous liberality. Alternatively, the concept may not have been understood as specifically Aristotelian but as part of a more general topos that circulated throughout the early centuries and which was drawn on by both Luke and Aristotle. Similar topoi are explored by Plato, Stobaeus, Theophrastus, Pseudo-Anacharsis, among others. ${ }^{8}$

It cannot be conclusively determined whether or not Aristotle or other first century writers had a direct influence on Luke, but the potential for analogical comparison is rich. Although Aristotle was not understood as a possible influence upon Luke in medieval and early modern English Christianity, come the sixteenth century exegetes began to frequently explore a productive analogical structure between Aristotle's treatment of prodigality and Lk 15.11-32. Aristotle's Nicomachean Ethics was more widely purposed to decode the parable than any other nonbiblical text, due partly to this analogousness and partly to the sheer force of Aristotle's revived popularity. This trend was only further encouraged by the parable's adoption of its now-familiar title, the parable of the prodigal son.

\footnotetext{
${ }^{5}$ Aristotle, The Nicomachean Ethics, trans. D. Ross (Oxford: Oxford University Press, 2009), 60-1. 1119b27-31, 1120a24-7.

${ }^{6}$ D. L. Balch, "Household Codes," Greco-Roman Literature and the New Testament, ed. D. E. Aune (Atlanta: Scholars Press, 1988), 25-50; Dieter Lührmann, "Neutestamentliche Haustafeln und Antike Ökonomie," New Testament Studies 27.1 (1980): 83-97; P. Balla, The Child-Parent Relationship in the New Testament and its Environment (Tübingen: Mohr Siebeck, 2003), 167-9; D. Holgate, Prodigality, Liberality and Meanness in the Parable of the Prodigal Son (Sheffield: Sheffield Academic Press, 1999), 90-130.

${ }^{7}$ Holgate, 103.

${ }^{8}$ Holgate, 99-130. For other uses of $\dot{\alpha} \sigma \omega \tau i \dot{\alpha}$ and $\dot{\alpha} \sigma \omega \epsilon \omega \varsigma$ in the Bible and early Christianity, see W. Bauer, A GreekEnglish Lexicon of the New Testament and Other Early Christian Literature, trans. W. F. Arndt and F. Wilbur Gingrich, 4th rev. ed. (Chicago: University of Chicago Press, 1957), 119.
} 
There is, of course, some grey area between parable of the prodigal son acting as a title versus its role as a descriptor. This grey area is, however, far narrower than one might assume. Instances of the parable being referred to as that of a prodigal son are very rare, isolated, and do not appear to be part of larger trends before the English paratext was instituted. References to Lk 15.11-32 as the parable, example, or story of the filius prodigus are unusual prior to the sixteenth century. Although the parable had been occasionally referred to as the tale of a filius prodigus for at least a millennium, this was not consistent in biblical paratexts and the term did not appear in English. The OED cites 1456 as the earliest recorded instance of prodigal in English literature (prodigality dates from 1340), but prodigal son does not appear until the 1500 s. $^{9}$ Given the long history of its Latin counterpart it is very possible that earlier, heretofore unrecorded instances of prodigal son exist, but if they do their scarcity shows that they are not indicative of popular usage.

It is not until after the title's integration into biblical paratexts that the term begins to be used regularly. Prior to the sixteenth century, Vulgates designate the parable via contents pages, casus summarii, marginal notes, and other paratexts with an array of phrasings. Many include no denomination at all. Some title the parable that of the filius pascitur, while Gabriel Bruno's tabula alphabetica historiarum (authored 1492) that appears in a number of later Vulgates identifies the parable by extracts from Lk 15.2 and 15.12. From the late fifteenth century on, the most common designations are variants of filius prodigus or just prodigus, though such usage is not consistent in either biblical paratexts or exegeses. This was one of the more recognised means of identifying the parable by exegetes and is done so by Jerome, Pseudo-Chrysostom, Nicolas de Clamanges, and Erasmus (not, though, in his Novum Instrumentum Omne). The Novum Instrumentum Omne titles the parable with an extract from Lk 15.13 in its contents preceding Luke, filius peregre profectus est in regionem longinquam. This was possibly Erasmus' attempt to mimic the parable's titloi of the early Greek manuscripts such as the Codex Alexandrinus, which also uses the first half of Lk 15.13 to designate the parable. ${ }^{10}$ Erasmus' paratext had little influence on the English paratexts, which I will discuss in a moment, and so this title was not often picked up.

The filius prodigus phrasing present in some Vulgates is occasionally retained as a marginal note in English Bibles at Lk 15.11 while sometimes an analogous English note, 'the ryotouse sonne', fulfils this role. The English designation, 'parable of the prodigal son', however, does not hail directly from the Vulgates, but reaches the English texts via Jacques Lefèvre d'Étaples' translation of the Bible into French, the 1530 La Saincte Bible. This Bible also contains a table of contents authored by 'Mattieu Gramelin', a pseudonym of the pastor Thomas Malingre. Despite

\footnotetext{
9 “prodigal, adj., n., and adv.” OED Online. September 2015. Oxford University Press. http://www.oed.com/view/Entry/151939?rskey=IlAweX\&result=1 (accessed October 12, 2015).

${ }^{10}$ Erasmus, [Prefatory Material], Novum Testamentum Omne (Basileae, 1522), 1:fol. E6v.
} 
the title's appearance in the casus summarii as 'la parabole [...] du fils prodigue', ${ }^{11}$ this table identifies Lk 15 as only 'La parabole de cent oaille." ${ }^{12}$ This table is noteworthy as it is copied into the 1535 Olivétan Bible's 'Indice des principales matieres', where Lk 15 is designated as containing the "exemple de lenfant prodigue [sic]. ${ }^{13}$ Pierre Olivétan does not, however, include the casus summarii in his edition. Why Olivétan opted to omit this heading is unclear, though it is possible he worked with a different edition of the Latin Vulgate to Lefèvre that did not contain the heading.

From here, the table journeys from French to English and makes an appearance in the 1537 Matthew Bible. The casus summarii of this Bible does not contain the title, but we see the phrase appear in John Rogers' English translation of Malingre's table, the 'table of the pryncypall matters contayned in the Byble.' Here, for the first time in recorded history, an English Bible identifies the parable as a tale about 'the prodygall sonne.' ${ }^{14}$ This slightly predates the earliest given instance in the OED, which records the 1551 Matthew Bible. ${ }^{15}$ The table of principal matters, being rather combatively Protestant, was subsequently dropped from later editions, and is thus unlikely to be the predominant cause of the title's inclusion in later Bibles. The title makes but spotty appearances until the publication of the 1560 Geneva Bible. After this point, prodigal son appears with increasing frequency in English literature, though whether this popularity was caused by these publications or merely coincided with them is difficult to determine. The 1537 Matthew Bible provides the first instance of an English Bible including the term prodigal son in its pages.

As mentioned, Rogers did not include the prodigal son chapter heading in his 1537 Matthew Bible, and it is not until the publication of Edmund Becke's 1551 editions that we see this heading appear in an English Bible. ${ }^{16}$ All other Bibles from 1537 to 1551 either omit a heading entirely, or refer to the parable as that of the wasteful and riotous son - or, more commonly, the lost son, to complement its sister parables of the lost sheep and lost coin. Becke's two texts, which do contain the prodigal son heading, were published in 1551. His 1549 Bible does not contain it. One 1551 text is the complete revision of Richard Taverner's work; the other contains only the New Testament and is likely an early edition of what became his complete Bible. ${ }^{17}$ This Bible contains numerous footnotes, headers, and commentary added by Becke, including the infamous 'wife-beater' exhortation in I Pet. 3.7. ${ }^{18}$ In the header to Lk 15 , the following chapter is introduced as containing 'the parables of the loste shepe, of the groat that was loste, and of the

\footnotetext{
11 “Le Nouveau Testament," La Saincte Bible, ed. Jacques Lefèvre d'Étaples ([Antwerp], 1530), fol. D5v.

${ }^{12}$ La Saincte Bible, ed. Jacques Lefèvre d'Étaples, fol. C4r.

13 "Le Nouveau Testament," La Bible, ed. Pierre Robert Olivétan (Neuchâtel, 1535), fol. 102v.

${ }^{14}$ The Byble, ed. John Rogers ([Antwerp(?)], 1537), fol. C3r.

15 "prodigal, adj., n., and adv." OED Online.

16 "The New Testament," The Byble, ed. John Rogers, fol. 34v.

${ }^{17}$ The Byble, ed. Edmund Becke (London, 1551).

18 "The Newe Testament," The Byble, ed. Edmund Becke (London, 1551), fol. 101r.
} 
prodigall sonne, sheweth that Christe seketh not for the death of a sinner, but for his amendement. ${ }^{19}$ This heading is identical to that which appears in the 1551 aforementioned New Testament, The Newe Testament Newlye Corrected. ${ }^{20}$ This text is frequently not listed as the work of Becke, but it is easily identified by its 'wife-beater' footnote. The prodigal son heading is present in neither Becke's 1549 Bible nor the Taverner Bible that Becke revised to assemble these texts. It seems, therefore, that Becke is the first to include this English heading to Lk 15.

While Becke may have been instrumental in increasing the title's popularity, the appearance of a similar English paratext in the 1560 Geneva Bible can be more directly traced to the Olivétan Bible, the later editions of which Calvin revised. French Bibles were particularly influential on the paratext of the Geneva Bible, ${ }^{21}$ and much of the Geneva Bible paratext appears to be translated directly from the Olivétan Bible. The Geneva Bible goes so far as to not only preface Lk 15 with a casus summarium introducing the parable 'of the prodigal sonne' but also to include a page-heading to the same effect, thus subordinating half of Lk 15 to the prodigal son phrase. $^{22}$ The King James Bible contained the same headings; after its publication the title became nigh ubiquitous in English Bibles, and consequently the association survives to this day.

This use of prodigal reforged in English the semantic tie between the parable and Aristotle that had been originally present in the Greek $\dot{\alpha} \sigma \omega \tau i \alpha$ of Aristotle and Lk 15.13. In the Geneva and King James Bibles, $\zeta \tilde{\omega} v \dot{\alpha} \sigma \omega ́ \tau \omega \varsigma$ was still rendered as 'riotous living', but non-Greek versions of the Nicomachean Ethics invariably translated $\dot{\alpha} \sigma \omega \tau i \dot{\alpha}$ as prodigality: see the sixteenth century English translations that all give prodigality, and the Latin translations of Leonardo Bruni,

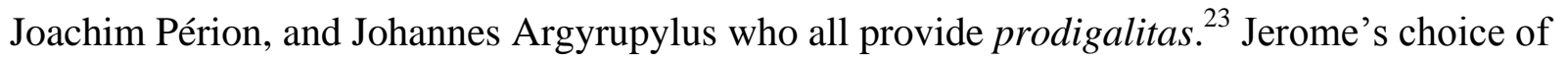
vivendo luxuriose over a variation of prodigus may be entirely responsible for the delay in widespread application of Aristotle to Lk 15.11-32 among English theologians.

This brief history lays the groundwork for some of the causes by which prodigal son became a ubiquitous title for Lk 15.11-32. The exact meaning of prodigal in this time period, however, and what its inclusion in the biblical paratext implied, are further issues worthy of discussion. In the mid-to-late sixteenth century, prodigal was strongly associated with the Aristotelian understanding of financial excess. At this time, Aristotelian philosophy was enjoying renewed popularity among English scholarship. His Nicomachean Ethics in particular was subject to a

\footnotetext{
19 "The Newe Testament," The Byble, ed. Edmund Becke (London, 1551), fol. 36v.

${ }^{20}$ The Newe Testament Newlye Corrected, ed. [Edmund Becke] (London, 1551), Early English Books Online, accessed 30 July 2015, http://gateway.proquest.com/openurl?ctx_ver=Z39.882003\&res_id=xri:eebo\&rft_id=xri:eebo:citation:180866571.

${ }^{21}$ F. Molekamp, "Genevan Legacies: The Making of the English Geneva Bible," in The Oxford Handbook of the Bible in England, c. 1530-1700, ed. K. Killeen et al. (Oxford: Oxford University Press, 2015), 42.

${ }^{22}$ The Geneva Bible (Peabody, Mass.: Hendrickson Bibles, 2007), fol. I4v.

${ }^{23}$ Aristotle, [Ethicorum Libros Facere Latinos Nuper Institui], trans. Leonardo Bruni ([Barcelona], [c. 1473]), 2:[book 4]; Aristotle, Ad Nicomachum Filium, trans. Joachim Périon (Basileae, 1552), 76; Aristotle, [Ethica ad Nicomachum], trans. Johannes Argyrupylus ([Paris], 1493), fol. E3r.
} 
dramatic surge in popularity over the sixteenth century, becoming one of the best-selling books of $1520^{24}$ and a core university text, studied by scholar and clergy alike. ${ }^{25}$ As Charles Schmitt argues, renaissance Aristotelianisms were 'not merely a blind continuation of the Aristotelianism of the Middle Ages' but an evolving integration of such thought into England's continually developing scholasticism and progressive philosophies. ${ }^{26}$ During and after the Reformation, varying forms of Aristotelianism were, as Schmitt phrases it, 'adopted [...] by essentially all segments of the newly fragmented European Christianity. ${ }^{27}$ Aristotelian scholarship thrived and informed a vast range of literatures and schools of thought during this time period, and not least of all among the work of ecclesiastical writers, where his philosophies retained a place of high regard. Largely in thanks to the work of Thomas Aquinas, Aristotle had long been considered compatible — or, at least, potentially compatible — with Christian doctrine, both Protestant and Catholic, and thus Aristotle retained a strong foothold in English universities after the Reformation. While there still existed vocal critics of using Aristotle in conjunction with biblical exegeses, Aristotle remained at the forefront of English philosophy and theology until well into the late seventeenth century.

Aristotle provided the exhaustive critical exposition on prodigality that the Bible lacked, and thus became the predominant cited authority on the (im)morality of financial excess in early modern England. Not all writers who utilise Aristotelian patterns had extensive or even first-hand experience with Aristotle's works. The pattern of excess, moderation, and deficiency was so widely disseminated that it is conceivable that some writers who invoked such a structure did so without knowledge of its origin; as the sixteenth century wore on, however, and Aristotelian scholarship flooded university textbooks and book sellers, more intimate familiarity with his work increased.

Prior to the early modern revival of Aristotelian scholarship, medieval exegeses of Lk 15.11-32 were far less concerned with Aristotelian interpretation than with allegorical readings. The major influences on these readings were Jerome's 21st letter, Ambrose's commentary on Luke, and Augustine's Questions, which formed the bedrock of medieval allegorical interpretation. ${ }^{28}$ Other commenters of note during this period include Bede, John Chrysostom, Tertullian, Peter Chrysologus, Rabanus, and Haymo of Halberstadt. ${ }^{29}$ As Aristotelian scholarship surged to prominence in England, however, a spate of Aristotelian exegeses of Lk 15.11-32 arose.

\footnotetext{
${ }^{24}$ T. Baldwin, William Shakespere's Small Latine \& Lesse Greeke (Urbana: Illinois University Press, 1944$), 103$.

${ }^{25}$ J. Scodel, Excess and the Mean in Early Modern English Literature (Princeton: Princeton University Press, 2002), 2.

${ }^{26}$ C. Schmitt, Aristotle and the Renaissance (Cambridge, Mass.: Harvard University Press, 1983$), 7$.

27 Schmitt, 26.

${ }^{28}$ S. Wailes, Medieval Allegories of Jesus' Parables (Berkeley: University of California Press, 1987), $239-42$.

${ }^{29}$ A. Young, The English Prodigal Son Plays, ed. J. Hogg (Salzburg: Salzburg University Press, 1979), 6-8.
} 
While performing an exhaustive examination of all early modern exegeses of Lk 15.11-32 that display these Aristotelian engagements would prove too monumental a task for this short article, I can address a number of significant examples. The following readings are taken from sermons published from the mid-sixteenth to the mid-seventeenth century, primarily from major theologians of the day. Of especial note are the sermons of Donne, which display perhaps the most vibrant engagement with Aristotle and the parable in the entirety of early modern literature. These sermons and other religious texts demonstrate a consistent and thorough integration of Aristotelian ethics and the parable at a level that cannot be found prior to the combined mid-tolate sixteenth century resurgence of Aristotelian scholarship and introduction of the parable's title into England's most widely-read Bibles.

The aforementioned discrepancy between the Greek New Testament and Jerome's Latin translation of $\mathrm{Lk} 15.13$ did not receive much attention in the early modern period, but neither did it go entirely unnoticed. Erasmus is the most prominent scholar to have made this observation. He writes: 'Hinc \& Paulus luxu vocat $\dot{\alpha} \sigma \omega \tau i ́ \alpha \mu$ [sic]: Vinum in quo est luxuria. Id autem non ad libidinem tantum pertinet. ${ }^{30}$ Erasmus does not dwell on the choice of translation, and he evidently did not disagree significantly with Jerome's choice as he also opts for vivendo luxuriose in his own translation of the New Testament. Despite the popularity of Erasmus's work, commentaries on this discrepancy remain rare, as is evidenced by a similar observation made apparently independently by the Puritan John Rainolds. Rainolds provides an Aristotelian exegesis of the Lukan son's prodigality in his popular work, Th'Overthrow of Stage-Playes, in which he cites the gospel's condemnation of the son's prodigality as biblical justification for his criticism of the expenses of theatrical productions. Here, Rainolds invokes the parable simply by reference to the 'prodigal son', demonstrating the saturation of the English term by the point of this work's publication in 1599. On the shared use of $\dot{\alpha} \sigma \omega \tau i \alpha$ in scripture and classical philosophy, Rainolds writes:

if you had considered that woord in the originall text of the Gospell, whereto my quotation for riott did direct you. For usually it noteth the qualitie of expenses made by loose \& wanton persons on their pleasures, as in forein writers, Aristotle and Tullie; so in Scripture likewise. ${ }^{31}$

He does not further expound this coincidence or speculate as to its causes. Rainolds' parallel citations of Aristotle and Luke are indicative of the respect Aristotle's account of prodigality continued to command as the sixteenth century came to a close, which would remain a worthy authority on the subject well into the late seventeenth century.

\footnotetext{
${ }^{30}$ Erasmus, Novum Testamentum Omne (Basileae, 1522), 2:169.

${ }^{31}$ John Rainolds, Th'overthrow of stage-playes ([Middelburg], 1599), 143-5.
} 
This linguistic association is also noted by Bishop Lancelot Andrewes, who provides an especially thorough discussion of Aristotle's writings on prodigality and its applicability to Christian teaching. He discusses at length Aristotle's formulation of excess and the mean as a way to understand a range of biblical passages including the Lukan parable, Ecc. 6.7, and 2 Cor. 9.11. Andrewes marries biblical doctrine and Aristotelian philosophy by integrating scripture and quotes from the Nicomachean Ethics to create an extensive explication of prodigality that remains grounded in Christian authority. He works from the Greek text and is thus able to draw relations between scripture and Aristotle's Nicomachean Ethics through the shared use of $\dot{\alpha} \sigma \omega \tau i \alpha$. His reading draws attention repeatedly to the extremes of human qualities, discussing the 'double extreme' of 'Profusion and Niggardness', and the subtle variations between different types of prodigality. Andrewes does not primarily ground his reading in scripture; indeed, as we have mentioned, there is no explicit denunciation of prodigality in the Bible, which led to works such as Andrewes' that take Aristotle as the core text for his exposition. ${ }^{32}$

The intersection of Aristotle's structure of qualities and the parable frequently produced a reading in which each of the three Aristotelian qualities aligned with each of the three major characters of the parable. Scripture itself identifies the son with prodigality, after which the father - who was widely believed to represent God — could be easily aligned with the virtuous mean of liberality. Such readings were facilitated by the popular perception of financial behaviours being polarised by age, although elderliness was variably associated with liberality and meanness, as evidenced by the popular proverb, 'A saving father, a spending son., 33 Aristotle expresses a similar age-affected sentiment, writing that many prodigals are 'easily cured both by age and by poverty; ${ }^{34}$ such an attitude is so broad, however, that we should be wary of attributing specifically Aristotelian origins to its instances without further evidence. The role of the elder brother was subject to more varied interpretation than the father and son, but it became common to associate him with meanness in order to complement the excessive son and the moderate father. The idea of an excessive vice that could be reformed into the mean also aptly communicated the reformative narrative of the parable and made the combination of Aristotle and Luke an especially popular topic for the many clergy who wished to preach on the corrigibility of the prodigal and exhort their audience to reform their immoderate ways. Examples of this feature in the divine Nehemiah Rogers' The True Convert, an extensive commentary on the parable with few non-biblical references, as well as Thomas Becon's The Sicke Mans Salve, William Burton's The Rowsing of the Sluggard, and John Carr's The Ruinous Fal of Prodigalitie. ${ }^{35}$

\footnotetext{
${ }^{32}$ Lancelot Andrewes, The morall law expounded (London, 1642), 803-5.

${ }^{33}$ M. P. Tilley, A Dictionary of the Proverbs in England in the Sixteenth and Seventeenth Centuries (Ann Arbor: Michigan University Press, 1950), 204.

${ }^{34}$ Aristotle, The Nicomachean Ethics, 63. 1121a20-1.

${ }^{35}$ Nehemiah Rogers, The true convert (London, 1620), 15, 86, 98, 116-7, 252-3; Thomas Becon, The sicke mans salve (London, 1570), 90; William Burton, The rowsing of the sluggard (London, 1598), 146; John Carr, The ruinous fal of prodigalitie (London, 1573), fols. [C]4r-D1r.
} 
While these themes and references abound throughout the work of minor clergymen, it is in the sermons of Donne that these suggestive cross-comparisons find their richest articulation. Little substantial work exists on the impact of the Nicomachean Ethics on Donne's writings, but its influence is commonly noted. ${ }^{36}$ His general engagement with Aristotle's golden mean has received some critical attention in recent years, especially in the work of Joshua Scodel, who has written extensively on Donne's use of the mean; ${ }^{37}$ however, Scodel concentrates on Donne's poetry and his engagement therein with the mean of courage and forms of the mean outside of Aristotelian qualities, and does not address the role of prodigality in Donne's work. This gap in scholarship is likely attributable to the general lack of research on prodigality as a concept, as Donne's treatment of the theme is especially vibrant and complex. The theme of prodigality in Donne's work is worthy of significant further study than can be undertaken here, but this article shall provide a preparatory reading that will hopefully prove of use to future research on the subject.

Although Donne does not nominally cite the Nicomachean Ethics, his treatment of prodigality is situated within an understanding of excess, moderation, and deficiency that is significantly informed by the Aristotelian schema. While this does not necessarily demonstrate a deliberate application of the structure surrounding moderation, Donne's understanding of prodigality and the ways in which he applies this to Lk 15.11-32 — are clearly influenced by that structure. Donne contrasts covetousness and prodigality: if 'the covetous man that heares me confesse my prodigality, should argue to himself, If prodigality, which howsoever it hurt a particular person, yet spreads mony abroad, which is the right and naturall use of money, be so heavy a sin, how heavy is my covetousnesse. ${ }^{38}$ Here, Donne engages with the issue that one's understanding of a deficiency, mean, or excess is highly contextually dependent; their definitions may be recontextualised by contrast to other degrees of prodigality/liberality/meanness. Donne addresses this problematic subjectivity elsewhere, though repurposes these difficulties to illustrate the variability of human language in contrast to divine providence: 'God hath given us out of his free bounty, and for meere thankes, all things for enough; but not any thing for too much. Who would depend any reckoning upon the breath of man or woman, when one and the same thing, shall have such variation in Epithetes, as what a friend calls bounteous liberallitie, an enemy calls lavish prodigalitie; so frugalitie penury; valour, foolehardinesse;' and so on. ${ }^{39}$ As is common in Donne's writing, he applies the financial terminology of bounty, liberality, and prodigality to a spiritual theme.

\footnotetext{
${ }^{36}$ R. Ray, A John Donne Companion (Oxon: Routledge, 2014), 38; P. McCullough, ed. The Oxford Edition of the Sermons of John Donne, vol. 1 (Oxford: Oxford University Press, 2015- ), 1:285, n. 203-5; S. Raman, “Can't Buy Me Love: Money, gender, and colonialism in Donne's erotic verse," Criticism 43.2 (2001): 144.

${ }^{37}$ J. Scodel, “The Medium Is the Message: Donne's 'Satire 3,' 'To Sir Henry Wotton' (Sir, More Than Kisses), and the Ideologies of the Mean,” Modern Philology 90.4 (1993): 479-511; Scodel, Excess and the Mean, 21-47.

38 John Donne, "Sermon XXXIII: Preached upon Whitsunday," LXXX sermons (London, 1640), 329.

${ }^{39}$ John Donne, Polydoron (London, 1631), 130-1.
} 
Donne understands these concepts' potential to slide into one another in the absence of due moderation, as expressed elsewhere in Donne's work: 'We have seen men infinitely prodigall grow infinitely Covetous at last. ${ }^{40}$ Donne's description of the 'natural use' of money also echoes Aristotle's writing on usury — an activity frequently associated with meanness - in which he denounces usury for 'mak[ing] a profit from currency itself, instead of making it from the process which currency was meant to serve,' and for usurers' employment of interest, 'as the offspring resembles its parent, so the interest bred by money is like the principal which breeds it, and it may be called "currency the son of currency." "41 Aristotle's view that such practices are 'unnatural' gained so much traffic in early modern England that David Hawkes goes so far as to argue that Aristotle's work was one of the major sources of the 'instinctive connection between usury and all forms of unnatural sexual activity' at this time. ${ }^{42}$ Donne's description of money being used naturally, especially in reference to covetousness, vividly recalls these Aristotelian arguments; furthermore, the 'use' may deliberately evoke usury by ironic contrast, 'use' being a verbal form of 'usury' and frequent source of related puns. ${ }^{43}$

Donne explains, 'Prodigality is a sin, that destroys even the means of liberality. ${ }^{, 44}$ Here, liberality implicitly figures as being comprised of the same behaviours as prodigality, albeit less intensely, for he that engages in such prodigal 'wast' then 'becomes unable to releive others.' 45 This understanding of liberality as a less extreme manifestation of the same behaviours that constitute prodigality is very Aristotelian. Donne emphasises the antithetical nature of prodigality and covetousness, arguing that sins 'excommunicate one another' and that 'covetousnesse will not be in the same roome with prodigality.' He concludes this particular passage by saying that, with age, the 'prodigal becomes covetous,' which displays the familiar alignment of age and financial behaviour. ${ }^{46}$ Elsewhere, Donne applies the prodigal/liberal contrast to judge those worthy of heavenly ascension: 'When we see some Authors in the Reformation afford Heaven to persons that never professed Christ, this is spirituall prodigality, and beyond that liberality which we consider now. ${ }^{47}$ Again, the financial schema is applied to spirituality. These contrasts would be so familiar to his audience that Donne can draw on them in ironic elaborations that rely on knowledge of the original Aristotelian formula. He writes, 'no man shall be call'd a prodigall, but onely the Covetous man,' because 'Onely he that hath been too diligent a keeper, shall appear to have been an unthrift, and to have wasted his best treasure

\footnotetext{
${ }^{40}$ John Donne, "Sermon X: Preached at the Churching of the Countesse of Bridgewater," Fifty sermons, 4th ed. (London, 1649), 77.

${ }^{41}$ Aristotle, Politics, trans. E. Baker (Oxford: Oxford University Press, 2009), 30. $1258 \mathrm{a} 35$.

${ }^{42}$ D. Hawkes, The Culture of Usury (Basingstoke: Palgrave Macmillan, 2010), 163.

${ }^{43}$ See "USE, n. A rich word for economic puns," in S. K. Fischer, Econolingua (Newark: University of Delaware Press, 1985), 133.

${ }^{44}$ John Donne, “A Sermon Preached at Greenwich: Aprill 30," Oxford Edition of the Sermons, 6.

${ }^{45}$ Donne, Oxford Edition of the Sermons, 6.

${ }^{46}$ Donne, "Serm. XXI: Preached at Lincolns Inne," Fifty sermons, 183.

${ }^{47}$ Donne, "LXXV Preached to the King at White-hall, April 15, 1628," LXXX sermons, 763.
} 
[...] his own soule. ${ }^{48}$ The rhetorical technique of ascribing prodigality to God to emphasise the Christian's undeserving appears in several early modern sermons, and is used again by Donne in his 'Elegy on Prince Henry', in which the speaker rhetorically asks, 'Oh, is God prodigall? hath he spent his store / Of plagues, on us, and onely now, when more / Would ease us much, doth he grudge misery; / And will not let's enjoy our curse; to dy' (45-8). ${ }^{49}$

Donne's personal definition of prodigality differs from the dominant early modern understanding in that he emphasises prodigality's defining quality not as excess but as that of waste. While this sense may be discernible in Aristotle's Greek, it is an atypical interpretation among early modern English writers. Donne emphasises opportunities lost through misspending, rather than the vice of misspending itself. This 'spirituall prodigality' ${ }^{50}$ (not a term coined by Donne) figures unrepented sin in terms of financial waste. Given that Donne discusses prodigality and the parable with such tight reference to one another, this emphasis on wastefulness may be due to the influence of Lk 15.13, in which the younger son 'wasted his goods with riotous living,' as given in the Geneva Bible and King James Bible. His poem 'Of Prodigality' expresses an example of this, in which the prodigal 'impetuously [...] pour[s]' down his means and so 'Tis soon gone' (23), but it also emerges as a general theme in his treatment of prodigality in his sermons, especially in reference to the parable. ${ }^{51}$

Donne conceptualises spiritual prodigality with legal and financial specificity. The metaphor presents a structural relation between the spiritual and the financial, wherein the financial vehicle constructs and specifies Donne's hermeneutics of spiritual prodigality. Lk 15.11-32 held especial interest to Donne, who primarily read it as an allegory for the importance of active repentance, ${ }^{52}$ as well as for the relationship between God, sin, and repentance as presented through the legal and financial implications of the prodigal son's wasting of his inheritance. Donne utilises the financial structure of the Aristotelian schema to interpret the parable's theme of spiritual expenditure in financial terms. Donne's most extensive treatment of prodigality and the parable is found in his sermon preached at Greenwich, 30 April 1615. This sermon begins with a detailed exposition on prodigality in relation to Isaiah 52.3: 'Ye have sold yourselves for nought; and ye shall be redeemed without money.' From here, Donne develops a hermeneutic of prodigality and the parable in which the prodigal son's financial waste allegorises our waste of free-will, and his repentance exemplifies the importance of contrition (sincere and active repentance) as opposed to attrition. Donne both interprets prodigality in the general sense of financial waste as well as the specific expenditure of one's inheritance, the former of which generates a broad and

\footnotetext{
${ }^{48}$ Donne, "Serm. XI: Preached at Lincolns Inne," Fifty sermons, 84.

${ }^{49}$ John Donne, The Complete Poems of John Donne, ed. R. Robbins (Harlow: Longman, 2010), 768-9.

${ }^{50}$ Donne, "Serm. LXV: Preached at White-Hall," LXXX sermons, 763.

${ }^{51}$ John Donne, Donne's satyr (London, 1662), 6, Early English Books Online, accessed 4 August 2015 http://gateway.proquest.com/openurl?ctx_ver=Z39.88-2003\&res_id=xri:eebo\&rft_id=xri:eebo:image:42803:10.

52 "I said I will go to my Father, A resolving and executing of that Resolution for that, that execution crownes all," Donne, "Serm. LVIII. Preached upon the Penitentiall Psalmes," LXXX sermons, 586.
} 
multifaceted metaphorical relation between appropriate financial behaviour and expenditure of free will in regard to sin.

Donne figures enacted sin in terms of finite financial resources, in which 'When thou art a Prodigal of thy soul' in sinning one may grow 'too poor for that purchase [of heaven];' in sinning we have 'sold' ourselves, which is a 'prodigal' transaction as we receive nothing in return. From this Donne derives hypothetical prodigalities, in which the Christian who is 'Prodigal of thy soul' yet expects Heavenly ascension without contrition asks God to 'be a prodigal too [...] and prostitute the kingdome of Heaven, for a sigh, or a groan, in which thy pain may have a greater part than thy repentance.' Here, Donne leads us to understand prodigality as entailing not just literal financial waste or even financial waste as metaphor for unrepented sin, but also as forgiveness expended wastefully on such unrepentants. Prodigality thus becomes a complex site for multiple meanings of waste and undeserving, derived from the intersection of the parable and Aristotelian ethical structures. ${ }^{53}$

Donne goes on to further elaborate this hermeneutic: 'God reproches to us, first, our Prodigality, that we would sell a reversion, our possibility, our expectance of an inheritance in heaven; And then, our cheapness, that we would sell that, for nothing.' Here, prodigality encompasses the foolish relinquishment of our potential for redemption through unrepentant sinning, as well as the emptiness of this transaction. He also focuses on the prodigal's specific wasting of his inheritance as both a metaphor for wasting free-will and as a prompt for examining these concerns in the context of probate law. He draws comparisons between bequeathing one's goods to relatives and one's soul to God: 'If his soul be under the weight of unreprented sins, God will do the devil no wrong, he will not take a soul, that is sold to him before.' This is intensified as he goes on to cite the Roman law exhceredatus creditur regarding the presumed disinheritance of a prodigal: 'And so also, if we have seen a man prodigal of his own soul, and run on a course of sin, all his life, except there appear very evident signs of resumption into Gods grace, at his end, Exhoredatus creditur, we have just reason to be afraid, that he is disinherited. ${ }^{, 54}$ This references a piece of Roman finance law, as explicated in the Digest of Justinian, wherein fathers may justifiably disinherit their sons. ${ }^{55}$ In the legal sense, Donne explains that financial prodigality is just cause to incur exhceredatus creditur, and from this premise he derives a spiritual elaboration: one who is prodigal of one's soul may similarly incur a spiritual exhceredatus creditur. ${ }^{56}$ Elsewhere, Donne again purposes this legal metaphor to articulate a spiritual concern, writing of exhoeredatus creditur in relation to God's disinheritance of the Jews, who 'more provoke[d]

\footnotetext{
${ }^{53}$ Donne, Oxford Edition of the Sermons, 7.

${ }^{54}$ Donne, Oxford Edition of the Sermons, 6-7.

${ }^{55}$ Saint Justinian, Digest of Justinian, ed. A. Watson, vol. 4 (Philadelphia: University of Pennsylvania Press, 1985), 68. 42.5.31.

${ }^{56}$ Donne, Oxford Edition of the Sermons, 6-7.
} 
Almighty God, then any children, any father. ${ }^{57}$ Donne thus develops the idea of spiritual prodigality from a financially specific (and Aristotelian) understanding of excess regarding financial behaviour.

Donne's financial understanding of spiritual prodigality further informs his conceptualisation of repentance as derived from Lk 15.11-32. Prodigality as describing wasteful financial behaviour provides Donne with a metaphor for the wasting of one's soul through unrepented sin that he allegorises through the parable, which positions the son's repentance as the ultimate repudiation against both prodigal wastefulness and spiritual procrastination. In the Greenwich Sermon, these comparisons precede an exegesis of the parable itself, removing any doubt that these discussions of inheritance and prodigality are indeed derived in part from Lk 15.11-32. Finally, Donne reads the parable as a reply to the Fall of Adam. For Donne, Adam is the ur-prodigal who 'spent it [his free-will] utterly. ${ }^{, 58}$ The prodigal son thus becomes an exemplar for all humanity whose repentance answers Adam's Fall, and we may either repent as the prodigal did or prodigally waste our souls: 'we are all prodigall sonnes, and not disinherited; we have received our portion, and misspent it, not bin denied it. ${ }^{59}$

Throughout Donne's work we see the Aristotelian concept of prodigality interwoven with Lk 15.11-32 so tightly that they can hardly be extricated. The ethical schema derived from Aristotle's Nicomachean Ethics provides Donne with a financially specific understanding of prodigality. He presents an exegesis of the parable in which repentance and spiritual prodigality are related to one another in light of the Aristotelian understanding of waste and excess. With Aristotle's text in mind, Donne's reading can be better understood and both the potential and actualised relations between the parable and Aristotelian prodigality in early modern England more clearly seen. In Donne's work, the intersection of Aristotelian ethics and the Lukan parable crystallise into symbiotic hermeneutics that produces some of the most intricate and rewarding readings of both texts and marks the zenith of their intersection in early modern England.

While Aristotelian readings of Luke may stretch back to the creation of the scripture, among English scholarship such readings did not become common until the late sixteenth century. With the integration of the prodigal son title into first the Matthew, Becke, Geneva, and finally King James Bibles came the absorption of a word steeped in Aristotelian connotation into the scripture's paratext. Ironically, the concept of the prodigal son lost its association with Aristotelian prodigality due to just how dominant the descriptor of 'prodigal' became. Having been integrated into the King James Bible, the title persisted while the Aristotelian context receded from popular knowledge as Aristotle fell out of favour in the late seventeenth century.

\footnotetext{
${ }^{57}$ Donne, "SERMON XLI., Preached at Saint Pauls Crosse. 6 May. 1627," Fifty sermons, 377.

${ }^{58}$ Donne, Fifty sermons, 51-2; Donne, Oxford Edition of the Sermons, 12.

${ }^{59}$ John Donne, Devotions upon emergent occasions, 2nd ed (London, 1624), 14.
} 
It has been the primary intent of this article to draw attention to the influence of Aristotelian ethics upon early modern interpretations of $\mathrm{Lk}$ 15.11-32. While it has focused on theological exegeses, these observations have further application in other interpretations of the parable, such as its depiction in visual art - tapestry, stained glass, textiles, carvings, etc. — and especially dramatic adaptation. The hugely popular 'prodigal son plays' that occupied the English stage for almost 150 years frequently display structural evidence of Aristotelian ethics, and may in fact have contributed to the parable's popularity and means of interpretation in religious literature. While determining the exact extent to which Aristotelian ethics influenced interpretation of the Lk 15.11-32 may remain too complex to achieve, we can say for certain that the influence was indeed present and far-reaching.

Today, the word prodigal has shifted almost beyond recognition and so-called 'prodigal sons' are designated as such with little regard for their wasteful habits. While there is little hope in rectifying this semantic shift (and perhaps the loss is no great tragedy), this research hopes to assist in the understanding of where such trends originated, and improve our knowledge of both Aristotelian exegeses and one of the most famous tales of Western Christianity. 